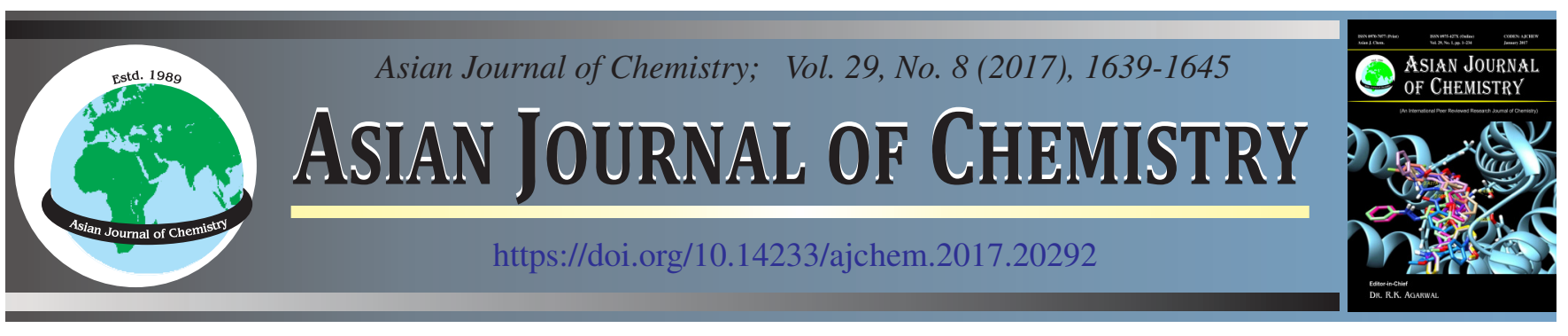

\title{
Selected Gaseous Pollutants Level in Ambient Air Around the Vicinity of Chemical Industry in Kwekwe, Zimbabwe
}

\author{
Joseph Simbi ${ }^{1}$, Beatrice Olutoyin Opeolu ${ }^{1}$ and Olatunde S. Olatunji ${ }^{2, *}$
}

${ }^{1}$ Department of Environemetal Health and Occupational Studies, Faculty of Applied Sciences, Cape Peninsula University of Technology, Cape Town, South Africa

${ }^{2}$ Department of Chemistry, Faculty of Applied Sciences, Cape Peninsula University of Technology, Cape Town, South Africa

*Corresponding author: Tel: +27 822912934; E-mail: snf_olatunji@ymail.com

\begin{abstract}
The integrity of the natural composition of air have been compromised by the emission of chemical, biological and particulate substances from diverse sources, and this has led to the changing dynamics of the cloud density of naturally occurring gases. There is paucity of information on the levels, characterization and real time variability of ambient air contaminants in the atmospheric environments of most urban and industrial layouts in many Africa cities. In this study, the ambient air concentrations of selected gaseous pollutants was investigated in nine sampling stations, randomly identified in the vicinity of a Chemical and Fertilizer Production Industry in Kwekwe, Zimbabwe. An electrochemical measuring transducer (Drager 5000-x Sensor) was used for the measurement of gaseous concentration of ammonia, sulphur dioxide and nitrogen dioxide under atmospheric conditions, in all wind directions at each station. The concentrations of $\mathrm{NH}_{3}, \mathrm{SO}_{2}$ and $\mathrm{NO}_{2}$ measured at all sampling stations within and around the study site were variable and ranged; 0.36-7.36 ppm; 0.02$84.61 \mathrm{ppm}$; and $0.61-34.78 \mathrm{ppm}$, respectively. The observed concentrations were significantly higher $(\mathrm{p}<0.05)$ than measured at the control sampling station, $5 \mathrm{~km}$ from the industry $\left(\mathrm{NH}_{3} ; 0.01-0.05 \mathrm{ppm}: \mathrm{SO}_{2} ; 0.03-0.18 \mathrm{ppm}: \mathrm{NO}_{2} ; 0.17-1.30\right.$ ppm). This may probably be because of air diffusion arising from the dispersion of the contaminants vis-a-viz molecular diffusion and convection through the air. Isokinetic and dissipation of the measured gases confirmed a distance dissipation pattern; hence the cloud concentrations of ammonia, sulphur dioxide and nitrogen dioxide thins out at distances further away from the Industry. The contaminants variability within the plant may not be unconnected with releases from hotspots such as ammonia loops and valve leakage areas, and the prevailing meteorological conditions.
\end{abstract}

Keywords: Pollution, Impacts, Ammonia, Sulphur dioxide, Nitrogen dioxide, Particulates, Sable chemicals.

L

\section{INTRODUCTION}

The integrity of the natural composition of air has been compromised by chemical, biological and particulate substances emissions from diverse sources including natural and anthropogenic. Natural sources of air contaminants include forest fires, volcanoes, magma degassing and weathering processes. Anthropogenic sources are mostly the result of human activities (domestic and industrial), with combustion of fossil fuels being a major source. Industrial processes involving time dependent unit operations may emit substantial quantity of atmospheric contaminants: $\mathrm{CO}, \mathrm{CO}_{2}, \mathrm{SO}_{2}, \mathrm{NO}_{2}$, $\mathrm{NH}_{3}$, particulates and other wastes [1,2]. These emissions have been reported to have severe biological and environmental impacts such as the induction of stress on human and animal health and on earth's climate [3-5]. Major industries that generate large emission of $\mathrm{CO}, \mathrm{CO}_{2}, \mathrm{SO}_{2}, \mathrm{NO}_{2}, \mathrm{NH}_{3}$, also known as green house gases are the chemical and petrochemical production and refinery plants, fertilizers manufacturing industries, etc. The presence of these air pollutants in the atmosphere has resulted in dynamics of changes in the cloud density of naturally occurring gases, bearing in it many aerodynamic character airborne contaminants. As a result, the purity of air over a given sphere may be variable and time dependent. This implies that the real time concentration of air pollutants depends on the different emission sources within near and far distances, as well as climatic conditions. These contaminants may not persist for long in the atmosphere due to silting and settling. Rain precipitation may further bring contaminants cloud density to near zero. Olatunji and Osibanjo [6] reported that the concentrations of low vapour density airborne contaminants in air shows distance disintegration from its hotspot, as a result of the buffer capacity of the atmosphere which allows for their rapid diffusion.

According to World Health Organization, "clean air is considered to be a basic requirement of human health and well- 
being" [7]. The continuous pollution of air therefore poses a significant threat to human and environmental health worldwide. High concentrations and presence of air contaminant gases and particulates poses a potential health hazard. Although the extent and magnitude of the impacts of air pollution on human and environmental health is not fully understood, adverse health consequences arising from the exposure of humans, animals and plants to elevated atmospheric concentrations have been reported severally [8-16]. Air quality contaminants can cause diseases, deaths, damage to other living organisms such as food crops and aesthetics or other damages to the natural or built environment [17]. Ambient air pollution was reported to be responsible for $1.4 \%$ of all deaths, $0.8 \%$ of all disability and $2 \%$ of all cardiopulmonary diseases [18]. In year 2014, WHO report [19], air pollution was noted to have caused the deaths of around 7 million people worldwide in 2012. The deterioration of air quality has also been indicted to bear significant impact on climate change [20,21].

Attendant consequences of air pollution such as these and many more, underscores the importance of the monitoring and characterization of ambient air quality at local, regional and national levels. Also the periodic or annual acquisition of air quality inventory for natural, residential and industrial environments is crucial for environmental health management and policy derivation. In this study, the ambient atmospheric composition status of selected noxious air contaminants e.g., $\mathrm{NH}_{3}$, $\mathrm{SO}_{2}$ and $\mathrm{NO}_{2}$ within and around Sable Chemical Industry in Kwekwe, Zimbabwe were investigated, with a view to determine possible anthropogenic enhancement arising from the production of fertilizer and other chemicals. Study results may serves as basis for the evaluation of the potential human and the environmental exposure risk and to create a baseline bench-mark for future environmental monitoring and air pollution control in order to facilitate sustainable environmental protection.

\section{EXPERIMENTAL}

Description of study location: The study location consists of the peripherals of the industrial layout of Kwekwe, Zimbabwe with Sable Chemical Industry (S.C.I.) as the epicentre (Fig. 1). Kwekwe which sits within the Midlands Province is a small mining town situated approximate $220 \mathrm{~km}$ from Harare and $230 \mathrm{~km}$ from Bulawayo.

Kwekwe is delimited by geo-reference coordinates 18.9167-19.0000 $\mathrm{S}$; latitude and $29.7500-29.8167^{\circ} \mathrm{E}$, longitude. It is in the Highveld at an altitude of about 1,220 $\mathrm{m}$ above the sea level. William and Smith [22] reported that the area is characterized by gently undulating topography. The district drainage is dominated by two north flowing rivers, the Kwekwe and the Sebakwe whose content are delivered into Munyati river at about $8 \mathrm{~km}$ north of Kwekwe town. The annual rainfall ranged between $650-700 \mathrm{~mm}$ with average annual temperature of $19^{\circ} \mathrm{C}$. The vegetation is characterized by short shrubs and tall grass.

Sampling stations and delineation of assessment study area: Nine air quality-monitoring networks were established to measure the concentration of $\mathrm{NH}_{3}, \mathrm{SO}_{2}$ and $\mathrm{NO}_{2}$ within and around the vicinity of S.C.I. near Kwekwe in Zimbabwe between July and September 2012 (Fig. 2). The 9 networks of data

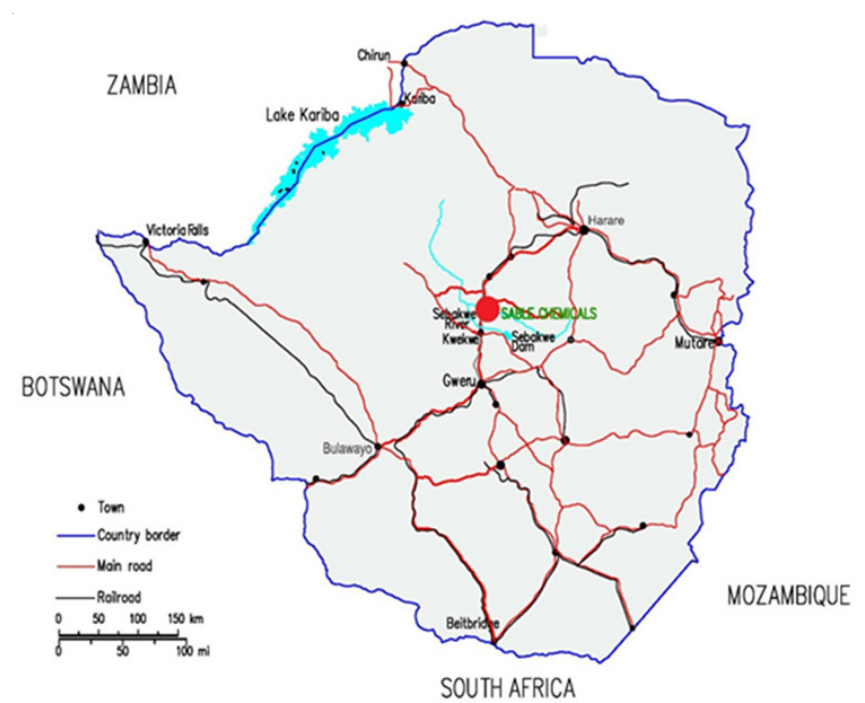

Fig. 1. Map of Zimbabwe showing the location of Kwekwe and the Sable Chemical Industry Position of (S.C.I) in Zimbabwe

logging stations were randomly identified and arranged in such an order as to capture air quality data in all wind directions (Fig. 2). The data logging points are, ammonia synthesis plant (loop), nitric acid plant, ammonium nitrate plant, boiler, samples were also taken $500 \mathrm{~m}$ from the centre of the ammonium plant towards the North South, East and West. Control sampling point was established about $5 \mathrm{~km}$ away from the centre of the ammonia synthesis plant (loop) towards the North-West. (i.e. the general windward direction in the area). All the measurements were carried out at a height approximately $1.5 \mathrm{~m}$ above the ground (shoulder height).

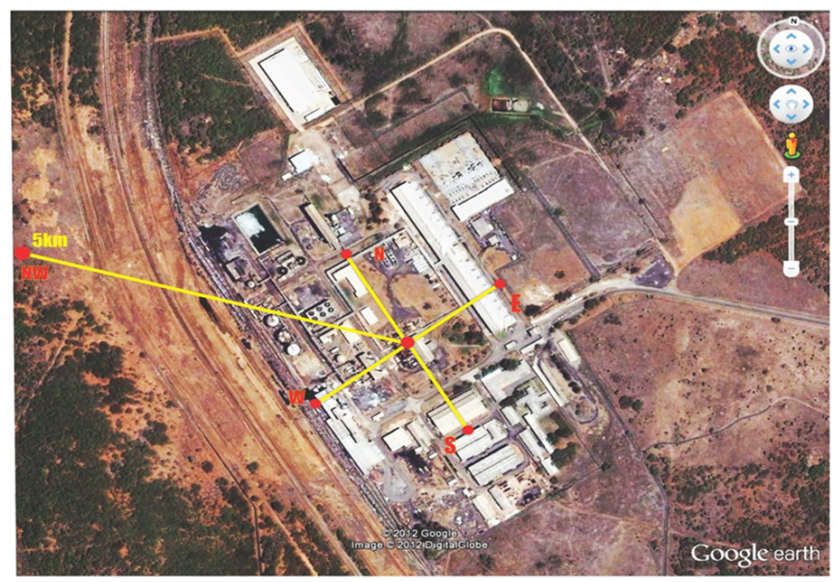

Fig. 2. Sable Chemical Industry google map showing the nine sampling points

Monitoring/sampling frequency and study duration: Air monitoring for the atmospheric levels of $\mathrm{NH}_{3}, \mathrm{SO}_{2}$ and $\mathrm{NO}_{2}$ was conducted thrice a week for three months: July; August; September 2012. A total of 324 data captures was achieved using an air sampling plan which achieves 9 data loggings per day (i.e. a sampling frequency of 27 per week or 108 per month) as modified from Gibson et al. [23]. All the data moni-toring loggings were conducted between the hours of 07.00-17.00 h on each expedition. 
Air measurement/log in of $\mathrm{NH}_{3}, \mathrm{SO}_{2}$ and $\mathrm{NO}_{2}$ concentrations: Drager X-am 5000 automatic multi-gas monitor was used to measure the atmospheric concentrations of $\mathrm{NH}_{3}$, $\mathrm{SO}_{2}$ and $\mathrm{NO}_{2}$ gases. The electrochemical Drager sensors rely on electrochemical measuring transducers, with capacity to measure $\mathrm{NH}_{3}, \mathrm{SO}_{2}, \mathrm{NO}_{2}, \mathrm{CO}, \mathrm{H}_{3} \mathrm{~S}, \mathrm{CO}_{2}, \mathrm{Cl}_{2}, \mathrm{HCN}, \mathrm{O}_{3}, \mathrm{COCl}_{2}$, amines, odorants and organic vapours [24,25].

Briefly, ambient air at the monitoring stations were allowed to diffuse through a membrane into the liquid electrolyte containing three sensor electrodes; a sensing electrode, a counter electrode and a reference electrode. The electronic potentiostate-circuit of the gas monitor was optimally set to ensure a constant electrical voltage between sensing electrode and reference electrode. The operational voltage applied, electrolyte and electrode material are selected to suit the gas being monitored, such that it electrochemically transform the flowing gas concentration to sensor detectable electrons, which is then measured as the gas concentration. The measured concentration of the gas is a function of the flow of electrons generated by the reaction.

\section{RESULTS AND DISCUSSION}

The $\mathrm{NH}_{3}, \mathrm{SO}_{2}$ and $\mathrm{NO}_{2}$ electrochemical transducer sensors of the automatic ambient air multi-gas monitor (Drager X-am 5000) consisting of an electrolytes, electrode(s) for sensing different gases, a counter electrode and a reference electrode were calibrated prior to measurement and acquisition of data at the selected sampling stations. The accuracy of the multigas sensor at calibration was $\leq \pm 2 \%$ within a measuring range of 0-50 ppm of $\mathrm{NO}_{2}$, for the measured value of $\mathrm{NO}_{2} ; \leq \pm 3 \%$ within a measuring range of $0-300 \mathrm{ppm} \mathrm{NH}_{3}$, for the measured value of $\mathrm{NH}_{3}$ and $\leq \pm 2 \%$ within a measuring range of $0-100$ ppm $\mathrm{SO}_{2}$, for the measured value of $\mathrm{SO}_{2}$ (Table-1). The instrument response time was $15 \mathrm{~s}$ at $20{ }^{\circ} \mathrm{C}$ for $\mathrm{NO}_{2}$ and $\mathrm{SO}_{2}$ and $20 \mathrm{~s}$ at $20{ }^{\circ} \mathrm{C}$ for $\mathrm{NH}_{3}$.

Concentration levels of $\mathrm{NH}_{3}, \mathrm{SO}_{2}$ and $\mathrm{NO}_{2}$ : Ammonia, $\mathrm{SO}_{2}$ and $\mathrm{NO}_{2}$ were detected at nearly all the gas monitoring network station within and around S.C.I. Toxic gases such as
$\mathrm{NH}_{3}, \mathrm{SO}_{2}$ and $\mathrm{NO}_{2}$ are emitted during different unit operations in chemical and fertilizer production plants [13]. The result showed that the concentration levels of $\mathrm{NH}_{3}, \mathrm{SO}_{2}$ and $\mathrm{NO}_{2}$ detected in ambient air around the vicinity of S.C.I were variable with respect to sampling location, time of measurement and climatic factors. The distribution sequence of the abundance of the measured gases were in the order $\mathrm{SO}_{2}>\mathrm{NO}_{2}>\mathrm{NH}_{3}$. The measured ambient atmospheric levels of $\mathrm{NH}_{3}, \mathrm{SO}_{2}$ and $\mathrm{NO}_{2}$ are presented in Table-2.

The concentrations of all three gases varied significantly ( $\mathrm{P} \leq 0.05)$ over the study period, with the lowest and highest detection observed during late winter (August) and springs (September), respectively.

Ammonia: The detected concentration level of $\mathrm{NH}_{3}$ in all the sampling stations around S.C.I generally ranged between 0.36 and $7.36 \mathrm{ppm}$ (Table-2), with the least level observed at $500 \mathrm{~m}$ from the south loop during July and highest by the $\mathrm{NH}_{3}$ synthesis plant loop, during August. The levels of $\mathrm{NH}_{3}$ at the different sampling stations were ranged 2.78-7.36 ppm at ammonia synthesis plant; $0.86-5.54$ ppm at the nitric acid plant; $1.57-5.84 \mathrm{ppm}$ at the ammonia nitrate plant; $2.03-7.07 \mathrm{ppm}$ at the boiler; 0.36-0.64 ppm at $500 \mathrm{~m}$ from loop South; 2.00$7.61 \mathrm{ppm}$ at $500 \mathrm{~m}$ loop west; $2.21-7.30 \mathrm{ppm}$ at $500 \mathrm{~m}$ loop North; and 0.90-1.86 ppm at $500 \mathrm{~m}$ loop east. These concentrations were significantly higher $(\mathrm{P}<0.05)$ than measured at the control site (0.01-0.05 ppm). The higher concentration value of $\mathrm{NH}_{3}$ detected near the ammonia plant (loop) was not unexpected due to the production of ammonia and this is consistent with the observations of Godson et al.'s findings [26].

Sulphur dioxide: The levels of $\mathrm{SO}_{2}$ generally ranged between 0.02-84.61 ppm in all sampling stations. The concentrations of $\mathrm{SO}_{2}$ at the different sampling stations (Table-2) were 0.17-69.32 ppm at the ammonia synthesis plant; 28.76-69.28 ppm at the nitric acid plant; $7.17-30.77$ ppm at the ammonia nitrate plant; 7.28-84.61 ppm at the boiler; nd-7.14 ppm at $500 \mathrm{~m}$ from loop south; 7.18-14.28 ppm at $500 \mathrm{~m}$ loop west; nd-69.23 at $500 \mathrm{~m}$ loop north; and nd-0.04 ppm at $500 \mathrm{~m}$

\begin{tabular}{ccccccc}
\multicolumn{7}{c}{ TABLE-1 } \\
& & & & \\
\hline Pollutants & Measuring range & Response time & Accuracy & Temperature & Humidity & Pressure \\
\hline $\mathrm{NO}_{2}$ & $0-50 \mathrm{ppm}$ of $\mathrm{NO}_{2}$ & $15 \mathrm{~s}$ at $20^{\circ} \mathrm{C}$ & $\leq \pm 2$ of the measured value & $-30-50{ }^{\circ} \mathrm{C}$ & $10-90 \%$ r.h. & $700-1300 \mathrm{hPa}$ \\
$\mathrm{NH}_{3}$ & $0-300 \mathrm{ppm} \mathrm{NH} \mathrm{NH}_{3}$ & $20 \mathrm{~s}$ at $20^{\circ} \mathrm{C}$ & $\leq \pm 3$ of the measured value & $-40-50{ }^{\circ} \mathrm{C}$ & $10-90 \%$ r.h. & $700-1300 \mathrm{hPa}$ \\
$\mathrm{SO}_{2}$ & $0-100 \mathrm{ppm} \mathrm{SO}{ }_{2}$ & $15 \mathrm{~s}$ at $20^{\circ} \mathrm{C}$ & $\leq \pm 2$ of the measured value & $-30-50{ }^{\circ} \mathrm{C}$ & $10-90 \%$ r.h. & $700-1300 \mathrm{hPa}$ \\
\hline
\end{tabular}

TABLE-2

CONCENTRATIONS OF $\mathrm{NH}_{3}, \mathrm{SO}_{2}$ AND $\mathrm{NO}_{2}$ AS MEASURED AT THE DIFFERENT SAMPLING POINTS

\begin{tabular}{|c|c|c|c|c|c|c|c|c|c|c|c|c|}
\hline \multirow[b]{2}{*}{ Sampling points } & \multicolumn{4}{|c|}{$\mathrm{NH}_{3}$} & \multicolumn{4}{|c|}{$\mathrm{SO}_{2}$} & \multicolumn{4}{|c|}{$\mathrm{NO}_{2}$} \\
\hline & July & Aug. & Sept & $\begin{array}{c}\text { Mean } \pm \\
\text { Std. Dev. }\end{array}$ & July & Aug. & Sept & $\begin{array}{c}\text { Mean } \pm \\
\text { Std. Dev. }\end{array}$ & July & Aug. & Sept & $\begin{array}{c}\text { Mean } \pm \\
\text { Std. Dev. }\end{array}$ \\
\hline Ammonia synthesis plant (loop) & 2.78 & 7.36 & 5.84 & $5.33 \pm 2.33$ & 14.34 & 0.17 & 69.32 & $26.94 \pm 36.53$ & 4.23 & 0.61 & 34.78 & $12.68 \pm 18.77$ \\
\hline Nitric acid plant & 2.17 & 0.86 & 5.54 & $2.79 \pm 2.41$ & 42.88 & 28.76 & 69.28 & $46.43 \pm 20.57$ & 5.09 & 1.24 & 23.86 & $9.73 \pm 12.10$ \\
\hline Ammonia nitrate plant & 2.78 & 1.57 & 5.84 & $3.34 \pm 2.20$ & 7.17 & 28.6 & 30.77 & $21.97 \pm 13.04$ & 0.71 & 1.43 & 0.61 & $0.97 \pm 0.45$ \\
\hline Boiler & 2.03 & 2.07 & 7.07 & $3.65 \pm 2.90$ & 21.56 & 7.28 & 84.61 & $36.68 \pm 41.15$ & 0.76 & 0.76 & 0.76 & $0.76 \pm 0.00$ \\
\hline $500 \mathrm{M}$ from loop South & 0.36 & 0.64 & 0.49 & $0.50 \pm 0.14$ & 7.14 & nd & 0.02 & $2.45 \pm 4.12$ & 0.73 & 0.76 & 0.77 & $0.75 \pm 0.02$ \\
\hline $500 \mathrm{M}$ from loop North & 4.44 & 2.21 & 7.30 & $4.59 \pm 2.55$ & 21.54 & nd & 69.23 & $29.31 \pm 35.43$ & 0.74 & 0.70 & 0.78 & $0.74 \pm 0.04$ \\
\hline $500 \mathrm{M}$ from loop East & 1.86 & 1.64 & 0.90 & $1.49 \pm 0.50$ & 0.04 & nd & 0.02 & $0.02 \pm 0.02$ & 0.72 & 0.71 & 0.71 & $0.72 \pm 0.01$ \\
\hline Control & 0.03 & 0.01 & 0.05 & $0.03 \pm 0.02$ & 0.03 & 0.03 & 0.18 & $0.08 \pm 0.09$ & 0.17 & 0.67 & 1.30 & $0.7 \pm 0.57$ \\
\hline Study overall mean concentration & & & 1.80 & & & & 17.21 & & & & 3.55 & \\
\hline
\end{tabular}


loop east. The least $(0.02 \mathrm{ppm})$ and the highest $(84.61 \mathrm{ppm})$ level of $\mathrm{SO}_{2}$ were observed at $500 \mathrm{~m}$ from the loop east/south and by the boiler plant respectively, during September. These concentrations were significantly higher $(p<0.05)$ than measured at the control site (0.03-0.18 ppm).The highest mean concentration of $\mathrm{SO}_{2}$ was observed at the nitric acid plant with $46.43 \mathrm{ppm}$ followed by the boiler $36.68 \mathrm{ppm}, 500 \mathrm{~m}$ north from the loop $29.31 \mathrm{ppm}$, the loop $26.94 \mathrm{ppm}$, ammonium nitrate plant $21.97 \mathrm{ppm}$, while $\mathrm{SO}_{2}$ was not detected at the control station. The high $\mathrm{SO}_{2}$ by the nitric acid plant may be as a result of anthropogenic emission from combustion of coal in the boiler. Diab [27] reported that most of the $\mathrm{SO}_{2}$ comes from the combustion of coal containing as low as 0.5-7 \% sulphur and the emissions can be trans boundary over long distances if emitted by high stacks.

Nitrogen dioxide: The concentrations of $\mathrm{NO}_{2}$ measured within and around the study site are very variable and ranged between 0.61-34.78 ppm (Table-2). The mean levels of $\mathrm{NO}_{2}$ observed at the different sampling stations within and around the study locations were ranged: ammonia synthesis plant, 0.61-34.78 ppm; nitric acid plant, 1.24-23.86 ppm; ammonia nitrate plant, $0.61-1.43 \mathrm{ppm}$; boiler, $0.76-0.76 \mathrm{ppm}$; at $500 \mathrm{~m}$ from loop south, 0.73-0.77 ppm; at $500 \mathrm{~m}$ loop west, 0.710.79 ppm; at $500 \mathrm{~m}$ loop north, $0.70-0.78 \mathrm{ppm}$; and at $500 \mathrm{~m}$ loop east, $0.71-0.72 \mathrm{ppm}$. These detected concentrations were significantly higher $(\mathrm{p}<0.05)$ than measured at the control site, $(0.17-1.30 \mathrm{ppm})$. The least concentration $(0.61 \mathrm{ppm})$ was observed by the ammonia synthesis and the ammonium nitrate plants during August, while the highest level (34.78 ppm) was observed by the ammonia synthesis plant during September. The average mean concentration values tend to decrease outwards, away from the plant. Ammonia synthesis plant (loop) 9.73 ppm, nitric acid plant 0.97 ppm, boiler 0.75 ppm, $500 \mathrm{~m}$ from loop south $0.75 \mathrm{ppm}, 500 \mathrm{~m}$ from loop west $0.74 \mathrm{ppm}$, $500 \mathrm{~m}$ from loop north $0.72 \mathrm{ppm}$. This observation is consistent with the results of Lampard [28] who reported diminishing $\mathrm{NO}_{2}$ concentrations reaching an average of $0.49 \mathrm{ppm}$ at a distance of $700 \mathrm{~m}$.

Distribution of $\mathrm{NH}_{3}, \mathrm{SO}_{2}$ and $\mathrm{NO}_{2}$ around the study area (Sable Chemical Industry): Activities at the different sampling stations within and around the chemical plant appeared to have an input in the atmospheric concentration levels of the measured gases. For instance, a high mean concentration of $\mathrm{NH}_{3}(14.5 \mathrm{ppm}$ ) was detected at the ammonia plant (loop) (Fig. 3). Godson et al. [26] suggested that high mean atmospheric concentration levels of $\mathrm{NH}_{3}$ by the $\mathrm{NH}_{3}$ plant may be as a result of subtle release through leaks, or pressure venting during production operation. The levels varied with sampling station; $4.5 \mathrm{ppm}-\mathrm{NH}_{3}$ at about $500 \mathrm{~m}$ from the loop towards the north; $3.8 \mathrm{ppm}-\mathrm{NH}_{3}$ at $500 \mathrm{~m}$ windward direction towards the west; $3.6 \mathrm{ppm}-\mathrm{NH}_{3}$ by the boiler and $0.03 \mathrm{ppm}$ at the control station. The highest mean concentration values of $\mathrm{NH}_{3}$ were observed in the month of September (Fig. 3). This was followed by levels detected in August and then July.

The highest mean concentration of $\mathrm{SO}_{2}(36.68 \mathrm{ppm})$ was measured by the boiler (Fig. 4). The high concentration may be because of atmospheric addition from coal combustion used to supply energy which power the $\mathrm{SO}_{2}$ production plant. The

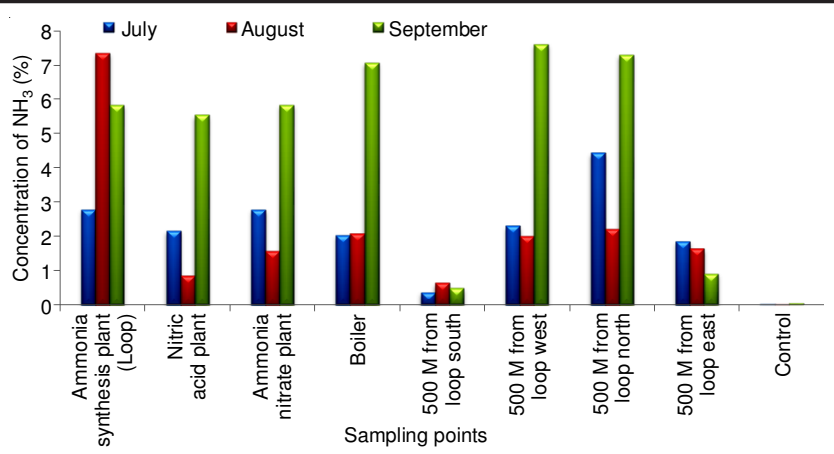

Fig. 3. Distribution of the mean monthly concentration of $\mathrm{NH}_{3}$ in the different sampling stations around Sable Chemical Industry

mean concentration values of $\mathrm{SO}_{2}$ however decreased with distance from the plant. Study results revealed that the mean concentration level of $\mathrm{SO}_{2}$ was highest during spring (September). This was followed by levels of $\mathrm{SO}_{2}$ observed during August and then July (Fig. 4). This observations are however contrary to the findings of Thakkar [15], who reported a higher value of gaseous pollutants $\left(\mathrm{SO}_{2}\right.$ : 19.40-56.12 ppm; $\mathrm{NO}_{\mathrm{x}}$ : 21.48$62.00 \mathrm{ppm}$ ) around the Gujarat State Fertilizer Company in India in winter than in summer.

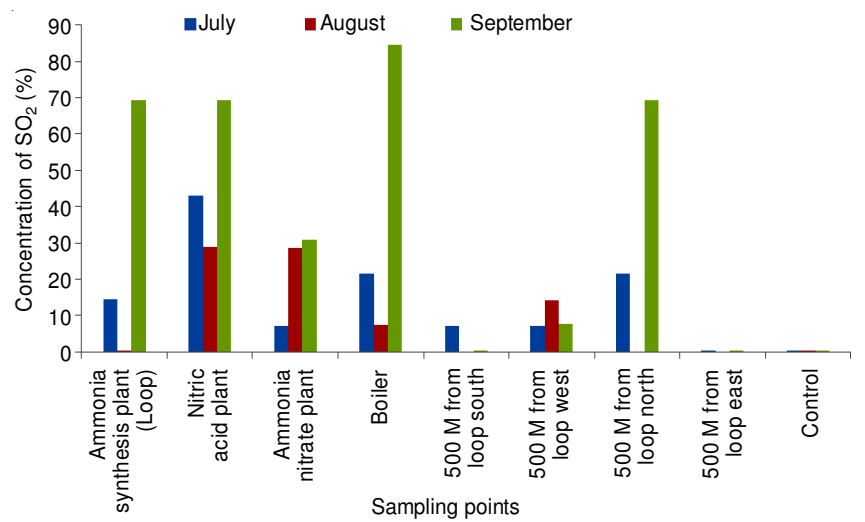

Fig. 4. Distribution of the mean monthly concentration of $\mathrm{SO}_{2}$ in the different sampling stations around Sable Chemical Industry

The highest mean concentration level of $\mathrm{NO}_{2}$ was observed at the ammonia synthesis plant (loop) in the month of September (Fig. 5) and this decreased with distance from the plant. The lowest $\mathrm{NO}_{2}$ concentrations were observed in the month of August. This may be because of the high winds observed during the period. Variations in the ambient air levels of $\mathrm{NO}_{2}$ may also be a result of chemical reactions in the atmosphere. According to Diab [27], nitric oxide reaches a maximum levels in ambient air in the early hours of the day at sunrise, after which $\mathrm{NO}$ is converted to $\mathrm{NO}_{2}$ resulting in increase of $\mathrm{NO}_{2}$ in the atmosphere. At the later hour of the day, ambient air $\mathrm{NO}_{2}$ also declines due to photo dissociation to form secondary pollutants such as $\mathrm{O}_{3}$.

Apart from the differences in operational activities at different sampling stations within and around the plant, the variations in levels of the measured gases may be associated with fluvial characteristics of gaseous and particulate substances. Thus, the dispersion of air pollutants from source areas into the atmosphere is governed by the processes of molecular diffusion and convection [29] and this depends on climatic 


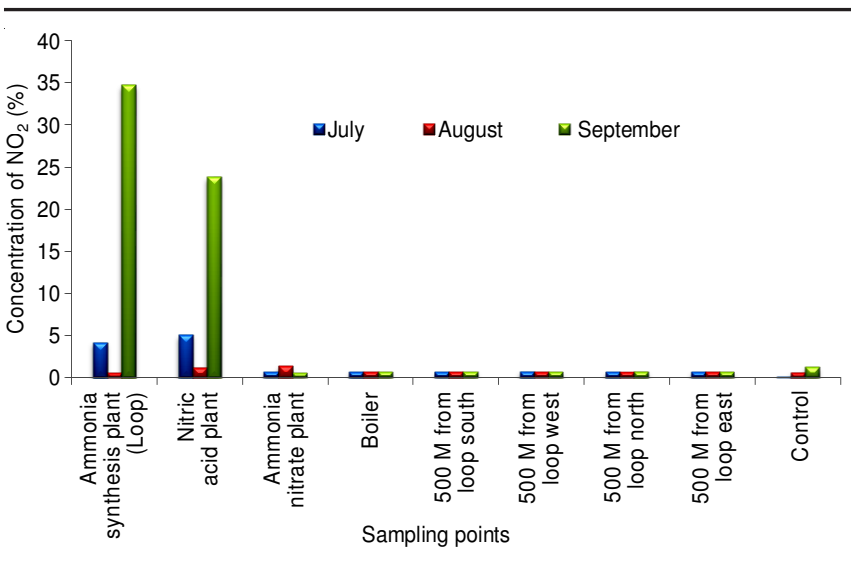

Fig. 5. Distribution of the mean monthly concentration of $\mathrm{NO}_{2}$ in the different sampling stations around Sable Chemical Industry

factors such as wind speed, temperature inversions and dry deposition. It is also evident that $\mathrm{NH}_{3}$ concentrations decreased with distance from the plant as $\mathrm{NH}_{3}$ gas was nearly at detection limit concentration quantities at the control point.

In general, the concentrations of the measured gases were higher in September. The higher concentrations of the gases detected in the month of September may be as a result of the characteristic relatively calm and hot climate noted in September. An average temperature of $18{ }^{\circ} \mathrm{C}$ and an average wind speed of $17 \mathrm{~km} / \mathrm{h}$ were reportedly captured for Zimbabwe during September by World Weather Online [30]. This could imply relatively high mean atmospheric pressure during the same period.

During climatic conditions such as this, some anthropogenic occurrences may interfere with natural processes of atmospheric interactions. High atmospheric pressure may result in increase in gas leakages from different pipe units. This could therefore result in slight elevation in the release of gaseous emissions from different sources such as pipe jointing's, flanges, valves and nozzles, apart from designated release points in the plant. The build-up of excess gases in the plants may consequently, result in pollution, poisoning and even explosions, on the one hand, while their levels around the plant may diminish via atmospheric deposition within the company premises [31].

The lower concentration levels of the gases observed in the month of August may however be the result of the generally cool and windy climate, with an average monthly temperature of $5-7{ }^{\circ} \mathrm{C}$ and an average wind speed is $75-76 \mathrm{~km} / \mathrm{h}$ [30]. This implies lower temperatures and less atmospheric pressure in around the plants. The high wind speed could also enhance the dispersal of emissions from the plant. Thus, as observed, the concentration levels of the gases are expected to be low within the plant and the surrounding areas. This is consistent with the observation of Lampard [28] who reported that the concentration of gaseous pollutants decreases with distance from Chemical Industry's Plant.
Comparative isokinetic and dissipation studies: The evaluation of the isokinetic and dissipation of the measured gases, using an isokinetic sampling train over a distance of about $5 \mathrm{~km}$ away from S.C.I, with the epicentres defined by the different sampling station within Sable Boundary Map, confirmed a common pattern of distance dissipation. This may be due to rapid mixing/diffusion into the blanket of atmospheric gases. Data were logged for the gases $\mathrm{NH}_{3}, \mathrm{SO}_{2}$ and $\mathrm{NO}_{2}$ from the windward direction, at average wind speed of 4 knots.

The results showed that the concentrations of the measured gases decreased with distance from the plant (Table-3, Fig. 6 ). The trend observed in this study is consistent with the findings of Lampard [28], who reported that particulate matter showed the highest concentration followed by $\mathrm{SO}_{\mathrm{x}}$ and then $\mathrm{NO}_{x}$.

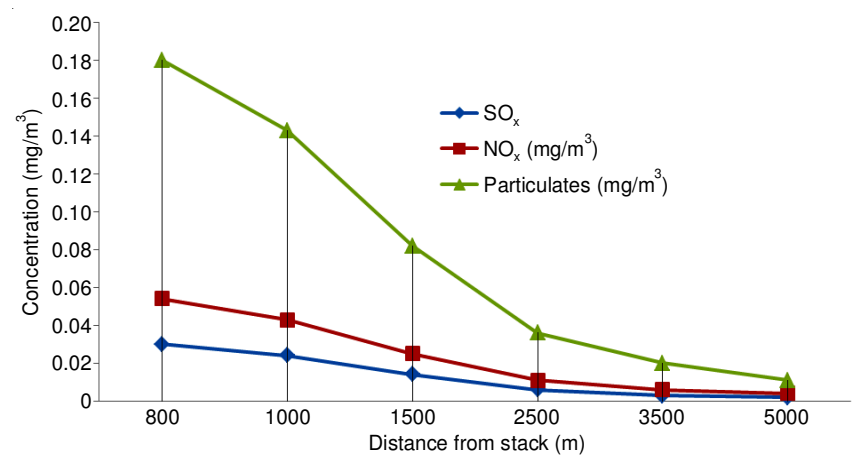

Fig. 6. Concentrations of $\mathrm{SO}_{\mathrm{x}}$ and $\mathrm{NO}_{\mathrm{x}}$ from the stack (x = number of atoms)

Isokinetic study showed that sampling point may partly account for the observed gas concentration value, thus humans, facilities and environment within the $1 \mathrm{~km}$ radius of the study area are at high risk of respiratory disease, especially children under the age of 12 years $[11,15,28]$.

Evaluation of ambient levels of $\mathrm{NH}_{3}, \mathrm{NO}_{2}$ and $\mathrm{SO}_{2}$ : Source apportionment, health and environmental implication: Ambient air quality can be impaired by emission from natural sources as well as from anthropogenic sources such as domestic and industrial combustion of fossil fuels. There are inherent dangers associated with elevated concentrations of $\mathrm{NH}_{3}, \mathrm{NO}_{2}, \mathrm{SO}_{2}$ and some other volatile materials in the atmosphere especially when in mixture with air (oxygen) in certain proportions.

The EPA reported that fertilizer production and livestock management contributes about $90 \%$ of the atmospheric $\mathrm{NH}_{3}$ [32]. The atmospheric lifetime of gaseous ammonia is however short and about $24 \mathrm{~h}$. Significant amount is often deposited or dissipated within near source points (700-1000 m). Ammonia in particulate form can travel much further impacting larger area. Thus ambient air levels are expected to be very low. Average of the total concentration of ammonia in ambient air around the study locations, revealed a mean concentration $3.53 \pm 2.10$

TABLE-3

CONCENTRATIONS OF $\mathrm{SO}_{x}$ AND NO${ }_{x}$ FROM THE STACK

\begin{tabular}{ccccccc}
\hline Distance from the stack $(\mathrm{m})$ & 800 & 1000 & 1500 & 2500 & 3500 & 5000 \\
\hline $\mathrm{SO}_{\mathrm{x}}\left(\mathrm{mg} / \mathrm{m}^{3}\right)$ & 0.030 & 0.024 & 0.014 & 0.006 & 0.003 & 0.002 \\
$\mathrm{NO}_{\mathrm{x}}\left(\mathrm{mg} / \mathrm{m}^{3}\right)$ & 0.024 & 0.019 & 0.011 & 0.005 & 0.003 & 0.002 \\
Particulates $\left(\mathrm{mg} / \mathrm{m}^{3}\right)$ & 0.126 & 0.100 & 0.057 & 0.025 & 0.014 & 0.007 \\
\hline
\end{tabular}


ppm. The observed concentration levels are low compared with levels (0.36-7.36 ppm) indicated for eliciting human and animal responses. In this study, the most intense perception of $\mathrm{NH}_{3}$ odour was at the $\mathrm{NH}_{3}$ synthesis plant loop (7.36 ppm), however pungent smell of $\mathrm{NH}_{3}$ is expected to be perceived at $\mathrm{NH}_{3}$ concentrations of $>50 \mathrm{ppm}$.

Human and animals may respond differently to exposure to different concentrations of $\mathrm{NH}_{3}$ over a short or long period of time. Inhalation of low concentration of $\mathrm{NH}_{3}$ can be tolerated for a very short time. This is because substantial proportion of the inhaled $\mathrm{NH}_{3}$ gas may also be exhaled within 30 min of absorption. However, inhalation of about 500 ppm (348 mg/ $\mathrm{m}^{3}$ ) $\mathrm{NH}_{3}$ may lead to the dissolution or absorption of $\mathrm{NH}_{3}$ in the mucous lining of the upper respiratory tract of human and animals [32,33]. Chronic exposure to relatively low concentrations, or acute exposure to concentrations greater than 500 $\mathrm{ppm}\left(348 \mathrm{mg} / \mathrm{m}^{3}\right)$ may saturate the scrubbing ability of the upper respiratory system and this may result in adverse effects on distal portions of the lungs including chronic respiratory disease [32,34].

Ammonia may affect vegetation by influencing the nitrogen cycle in the ecosystems and it may be harmful to plants exposed to it $[32,35,36]$. Both gaseous and particulate ammonia contribute to eutrophication of surface waters, soil acidification, fertilization of vegetation, changes in ecosystems and smog and decreased visibility in cities and pristine areas [37].

Naturally levels of $\mathrm{NO}_{2}$ vary widely because of a continuous baseline level present in the atmosphere. The annual mean concentrations of $\mathrm{NO}_{2}$ range from 0.4-9.4 $\mu \mathrm{g} / \mathrm{m}^{3}$. Results from animal experiments, revealed that exposure to $\mathrm{NO}_{2}$ at concentrations less than $1880 \mu \mathrm{g} / \mathrm{m}^{3}$ (1 ppm) rarely results in acute toxicity [7]. Human exposure to $\mathrm{NO}_{2}$ concentrations greater than $4700 \mu \mathrm{g} / \mathrm{m}^{3}$ (2.5 ppm) may lead to pronounced decrease in pulmonary function $[7,38]$. A plethora of effects on lung, spleen, liver and blood may occur [7,39]. Both reversible and irreversible lung effects such as structural changes in cell types in the tracheobronchial and pulmonary regions to emphysema like effects have been reported $[7,40]$. Biochemical changes often reflect cellular alterations at levels of 380-750 $\mu \mathrm{g} / \mathrm{m}^{3}(0.2-0.4 \mathrm{ppm}) . \mathrm{NO}_{2}$ levels as low as $940 \mu \mathrm{g} / \mathrm{m}^{3}(0.5 \mathrm{ppm})$ also increase susceptibility to bacterial and viral infection of the lung.

Humans and animals exposed to such ambient air levels of $\mathrm{NO}_{2}$ detected in the study area may be subject to $\mathrm{NO}_{2}$ health risk. This is because the average concentration observed was greater than the $1 \mathrm{ppm}$ threshold for the manifest of acute toxicity. However, the mechanisms of allergen challenges of $\mathrm{NO}_{2}$ are not fully defined since $\mathrm{NO}_{2}$ showed no effect at concentration as low as $190 \mu \mathrm{g} / \mathrm{m}^{3}(0.1 \mathrm{ppm})$ [7]. It is also not clear whether long term exposures to ambient $\mathrm{NO}_{2}$ has any health effect in adults, although available results suggest respiratory effects in children exposed to an annual average $\mathrm{NO}_{2}$ concentration of $50-70 \mu \mathrm{g} / \mathrm{m}^{3}$ or higher.

A major source of the release of $\mathrm{SO}_{2}$ is the combustion of fossil fuels, with coal accounting for nearly $50 \%$ of the annual global $\mathrm{SO}_{2}$ release and oil between $25-30 \%$ [7,38]. The average mean concentration value of $\mathrm{SO}_{2}$ measured during study was $19.3 \mathrm{ppm}$, lower than the annual mean concentrations of $\mathrm{SO}_{2}$ ranged $20-60 \mu \mathrm{g} / \mathrm{m}^{3}(0.007-021 \mathrm{ppm})$ reported in the atmos- phere around Europe [7]. In large cities with large traffic volumes or where coal is still being used, $\mathrm{SO}_{2}$ concentrations could be 5-10 times higher [41]. Peak concentrations can reach $1000-2000 \mu \mathrm{g} / \mathrm{m}^{3}(0.35-0.70 \mathrm{ppm})$ or higher.

Effects of $\mathrm{SO}_{2}$ exposure over an extended period were derived from epidemiological studies. Symptoms of lung infection was reported to be exacerbated in sensitive people consistently exposed to $\mathrm{SO}_{2}$ concentrations exceeding $250 \mu \mathrm{g} /$ $\mathrm{m}^{3}(0.087 \mathrm{ppm})$. Studies also revealed the mortality effects of $\mathrm{SO}_{2}$ exposure in industrial layouts and in high vehicular traffic locations. The annual average LOAEL of the sum of $\mathrm{SO}_{2}$ and particulate matter has been suggested to be $100 \mu \mathrm{g} / \mathrm{m}^{3}(0.035$ ppm) $[7,38]$. Although adverse health effects may occur at concentrations below this level; long term effects are liable to be affected by current conditions as well as the different qualitative and quantitative pollution $[17,38]$.

Sulphur dioxide stimulates nerves in the lining of the nose, throat and lungs thereby irritating them. This causes reflex cough and chest tightness, which may lead to narrowing of the airways. It is however not certain that adverse effects as a result of exposure to much lower concentrations of $\mathrm{SO}_{2}$ may occur, but rather, a surrogate for $\mathrm{SO}_{2}$ [38]. The World Health Organization, therefore recommends a concentration of 125 $\mu \mathrm{g} / \mathrm{m}^{3}$ over a period of $24 \mathrm{~h}$ and an annual average concentration of $50 \mu \mathrm{g} / \mathrm{m}^{3}$.

\section{Conclusion}

The mean concentration levels observed for $\mathrm{NH}_{3}, \mathrm{SO}_{2}$ and $\mathrm{NO}_{2}$ during study were ranged $3.8 \mathrm{ppm}, 19.3 \mathrm{ppm}$ and $3.1 \mathrm{ppm}$ respectively. The ambient levels of $\mathrm{NH}_{3}, \mathrm{SO}_{2}$ and $\mathrm{NO}_{2}$ into the blanket of atmosphere around the Fertilizer and Chemical production Industry were within the ambient levels considered to be safe when compared to the World Health Organization [7,38], the South Africa Air Quality Standards and Chapter 20.27 of the Environmental Management Act of Zimbabwe [42] guidelines. The cloud concentrations of $\mathrm{NH}_{3}, \mathrm{SO}_{2}$ and $\mathrm{NO}_{2}$ within the Fertilizer and Chemical production facilities of the Industry were higher than observed distances away from the Industry. This is probably as a result of air diffusion arising from the dispersion of contaminants through the air. There were variation in the concentration levels of each parameter measured within the plant. The variability may not be unconnected with release from hotspots such as the ammonia loop and valve leakage areas and the effect of the prevailing meteorological conditions at the time of measurement. Low surface wind speed, mixing height, temperature inversion, anticyclonic conditions, high pressure and poor maintenance within the plant may result in high pollutants concentrations.

Pollutants may however not stay long in the atmosphere; they can be deposited onto land and water near or far distances, providing the relationship between air qualities, water quality and ecosystem health. While the mean concentration values of pollutants in this study appear to be fairly low, findings from earlier studies showed that air pollutants can be damaging even at low concentrations. Thus, air quality issues should be considered and taken very seriously, because of their subtle and chronic ability to cause significant health and environmental damages and even death. 


\section{REFERENCES}

1. A. Daly and P. Zannetti, An Introduction to Air Pollution, Definitions, Classifications and History, The Arab School for Technology (ASST) and the EnviroComp Institute (2007).

http://www.envirocomp.org [12 March 2011].

2. G. Hutton, Alir Pollution, Global Damage Costs of Air Pollution from 1900 to 20150, Assessment Paper, Copenhagen Consensus of Human challenges (2011).

3. M. Beniston, Int. Rev. Red Cross, 92, 557 (2010); https://doi.org/10.1017/S1816383110000342.

4. B. Rani, U. Singh and R. Maheshwari, Adv. Biores., 2, 1 (2011)

5. J.L. Peel, R. Haeuber, V. Garcia, A.G. Russell and L. Neas, Biogeochemistry, 114, 121 (2013); https://doi.org/10.1007/s10533-012-9782-4.

6. S.O. Olatunji and O. Osibanjo, Asian J. Chem., 25, 4232 (2013); https://doi.org/10.14233/ajchem.2013.13911.

7. WHO, Air Quality Guidelines for Particulate Matter, Ozone, Nitrogen Dioxide and Sulphur Dioxide, Summary for Risk Assessment (2005).

8. S. Wood and A. Cowie, A Review of Greenhouse Gas Emission Factors for Fertiliser Production, Research and Development Division, State Forests of New South Wales, Cooperative Research Centre for Greenhouse Accounting, For IEA Bioenergy Task 38 (2004).

9. S. Ahlgren, A. Baky, S. Bernesson, A. Nordberg, O. Noren and P. Hansson, Bioresour. Technol., 99, 8034 (2008); https://doi.org/10.1016/j.biortech.2008.03.041.

10. P.P. Motavalli, K.W. Goyne and R.P. Udawatta, Crop Management, 7, (2008); https://doi.org/10.1094/CM-2008-0730-02-RV.

11. R.P. Prajapati and R. Singhai, J. Environ. Sci. Computer Sci. Eng. Technol., 1, 311 (2012).

12. Z. Kirova-Yordanova, Int. J. Thermodyn., 16, 163 (2013); https://doi.org/10.5541/ijot.471.

13. B. Singh, J. Hazard. Mater., 167, 24 (2009); https://doi.org/10.1016/j.jhazmat.2009.01.071.

14. T. Subramani, Int. J. Eng. Res. Appl., 2, 1753 (2012).

15. A. Thakkar, Int. J. Theoretical Appl. Sci., 5, 109 (2013).

16. Environmental Health and Engineering (EH\&E), Emissions of Hazardous Air Pollutants from Coal-Fired Power Plants (2011).

17. A.J. Chauhan and S.L. Johnston, Br. Med. Bull., 68, 95 (2003); https://doi.org/10.1093/bmb/ldg022.

18. WHO, Protection of the Human Environment, Geneva (2004) www.instituteforenergyresearch.org.

19. WHO, Burden of Disease from Joint Household and Ambient Air Pollution for 2012, Report No. 27, Geneva, Switzerland (2014).
20. D.J. Jacob and D.A. Winner, Atmos. Environ., 43, 51 (2009); https://doi.org/10.1016/j.atmosenv.2008.09.051.

21. D.T.T. Toan, V.D. Kien, K.B. Giang, H.V. Minh and P. Wright, Glob. Health Action, 7, 23025 (2014); https://doi.org/10.3402/gha.v7.23025.

22. T.M. William and B. Smith, Environmental Impacts of Gold and Complex Sulphide Mining: A Technical Report (1994).

23. M.D. Gibson, S. Kundu and M. Satish, Atmos. Pollut. Res., 4, 157 (2013); https://doi.org/10.5094/APR.2013.016.

24. P. Balashanmugaam, A.R. Ramanathan and V. Nehru Kumar, Int. J. Eng. Res. Appl., 2, 300 (2012).

25. Drager Booklet (2012).

26. R.E.E. Godson, K.C. Mynepalli and F. Joshua, J. Environ. Health Res., 4, (2005).

27. R. Diab, Types and Sources of Air Pollutants, University of KwaZuluNatal, Durban, South Africa (2011).

28. T. Lampard, Air Quality Risk Assessment, Sable Chemicals Limited, Totes (Pvt) Ltd Paramark, Harare, Zimbabwe (2011).

29. K. Lakshminarayanachari, K.L. Sudheer Pai, M.S. Prasad and C. Pandurangappa, Atmos. Pollut. Res., 4, 106 (2013); https://doi.org/10.5094/APR.2013.011.

30. Zimbabwe by World Weather Online (2014).

31. M.P. Tsimakuridze, Georgian Med. News, 124-125, 87 (2005)

32. World Bank and Associates, (WBK), Air and Water Pollution: Burden and Strategies for Control (2004).

33. Agency for Toxic Substances and Disease Registry (ATSDR), Public Health Statement Ammonia (2004).

34. J.D. Pritchard, Version, 2, 1 (2007).

35. A.C. Hill, J. Air Pollut. Control Assoc., 21, 341 (1971); https://doi.org/10.1080/00022470.1971.10469535.

36. A.C. Hill and J.H. Bennett, J. Air Poll. Control Assoc., 23, 203 (1973); https://doi.org/10.1080/00022470.1973.10469767.

37. G.M. Lovett, T.H. Tear, D.C. Evers, S.E.G. Findlay, B.J. Cosby, J.K. Dunscomb, C.T. Driscooll and K.C. Weathers, Ann. N. Y. Acad. Sci., 1162, 99 (2009); https://doi.org/10.1111/j.1749-6632.2009.04153.x.

38. WHO, Air Quality Guidelines for Europe, edn 2 (2000).

39. Agency for Toxic Substances and Diseases Registry (ATSDR), Nitrogen Oxides (2002).

40. L. Ferrari and J. Salisbury, Nitrogen Dioxide National Environmental Health Forum, vol. 11, pp. 1-34 (1997).

41. Acute Exposure Guideline Levels (AEGLS), Sulphur dioxide (2008). http://www.epa.gov/.

42. Environmental Management Act, Zimbabwe, Chap. 20, p. 27 (2002). 